\title{
Development of Microbial Consortia for the Management of Leaf Blight Disease of Coconut
}

\author{
I. JOHNSON ${ }^{1 *}$, R. RAMJEGATHESH ${ }^{2}$, J. SHEELA ${ }^{3}$, N. SHOBA ${ }^{2}$ \\ and H. P. MAHESHWARAPPA ${ }^{4}$ \\ ${ }^{1}$ Department of Plant Pathology, Tamil Nadu Agricultural University, Coimbatore-641 003, India \\ ${ }^{2}$ Coconut Research Station, Coimbatore (Dt.)-642 101 India \\ ${ }^{3}$ Department of Vegetables, Horticultural College and Research Institute, Periyakulam, Theni, India \\ ${ }^{4}$ Project Co-ordinator (AICRP on Palms), ICAR-CPCRI, Kasaragod, Kerala, India
}

(Received: 23 September 2016; accepted: 24 November 2016)

\begin{abstract}
The leaf blight disease caused by Lasiodiplodia theobromae is an important foliar disease in coconut that results in a yield reduction of 10-24 per cent in Tamil Nadu, India. In the present study, five Trichoderma viride isolates, Pseudomonas fluorescens and Bacillus subtilis strains were isolated from the coconut rhizosphere and tested against L. theobromae. P. fluorescens Pf1, B. subtilis (Km1) and T. viride (TNAU) isolates were found highly effective against the leaf blight pathogen under in vitro conditions and hence, all the three antagonists were combined together to develop microbial consortia and tested against leaf blight disease under field conditions. Soil application of microbial consortia formulated using talc as a carrier material at $150 \mathrm{~g}$ (50 g each) and $300 \mathrm{~g}$ (100 g each) doses at different intervals (quarterly, half-yearly and annually) was evaluated for three years from 2011 to 2013. Among the treatments, the fungicide carbendazim was found to be the most effective against coconut leaf blight. Among the treatments with bioagents, soil application of microbial consortia@300 g +5 kg of farm yard manure at quarterly interval/palm/year was the best treatment which was followed by the treatment with TNAU Bacillus subtilis (Bs1) mixture in two locations. Confirmatory results were obtained in similar experiments carried out at two different locations during 2013-2014, too.
\end{abstract}

Keywords: Coconut, Lasiodiplodia theobromae, microbial consortia, Pseudomonas, Bacillus, Trichoderma.

Leaf blight disease of coconut caused by Lasiodiplodia theobromae (Syn: Botryodiplodia theobromae) (Pat.) Griffon and Maubl. is an emerging problem in Tamil Nadu. Recent years, the disease is spreading at a faster rate in Coimbatore, Erode, Dindigul, Tirunelveli, Kanyakumari and other districts of Tamil Nadu. It was reported in India during 1984 by Raju (Raju, 1984), and it is also reported to cause coconut fruit (nut) rot in Brunei, Indonesia and Vietnam (Johnston, 1965). In case of nut infection, the affected nuts were desiccated, shrunk, deformed and dropped prematurely (Warwick et al., 1993; Lakshmanan and Jagadeesan, 2004) and resulting in nut yield loss up to 10 to $25 \%$. Even though several chemicals were found to manage the disease, the factors including devel-

\footnotetext{
* Corresponding author; e-mail: johnsonpath@gmail.com
} 
opment of fungicide resistance, residual toxicity and environmental pollution forced to develop an alternate method, obviously biological management.

Biological control by antagonistic organisms is established as a potential non-chemical tool for crop protection against phytopathogens (Papavizas, 1985). A directed biological control of pathogenic fungi in the field may be achieved by modifying the indigenous microbial community in such a way as to favour the destruction of the pathogen through various modes of actions.

Fluorescent pseudomonads were known to survive both in rhizosphere (Parke et al., 1991) and phyllosphere (Wilson and Lindow, 1992) and the antagonist P. fluorescens significantly inhibited the mycelial growth of Pestalotia palmarum (Karthikeyan and Bhaskaran, 1998). P. fluorescens isolated from the surface of healthy cocoa pods were antagonistic to Phytophthora palmivora both in vitro and in vivo and were more effective than cupric oxide or chlorothalonil in controlling black pod (Galindo, 1992).

Similarly, Trichoderma viride reduced the fruit rotting in banana caused by $L$. theobromae (Mortuza and Ilag, 1999) while, T. virens and T. hamatum were highly effective against $L$. theobromae by producing volatile metabolites (Swapna and Nagaveni, 2009; Johnson et al., 2014). Swain and Ray (2009) reported that Bacillus subtilis was highly effective against the post-harvest pathogens of yam, viz. L. theobromae and Fusarium oxysporum.

Development of microbial consortium based on their compatibility can reduce the possibilities of failure of potential microbial inoculants in the rhizosphere. Application of more than one biocontrol agent is a reliable means of reducing the variability and increasing the reliability of biological control. The use of several antagonists with different mode of action may improve biocontrol efficacy under wide range of environmental conditions (Grosch et al., 2011). The three-way mixture of plant growth-promoting rhizobacteria strains INR7 (B. pumilus), GB03 (B. subtilis) and MEI (Curtobacterium flaccumfaciens) as a seed treatment showed increased plant growth promotion and reduction of cucumber diseases (Raupach and Kloepper, 1998) under field conditions. Use of different bacterial species of P. aeruginosa, S. marcescens, Bacillus spp., B. subtilis, P. fluorescens etc. in biological control of plant pathogens have been reported by several workers (Asaka and Shoda, 1996; Someya et al., 2000; Kim et al., 2009; Suryadi et al., 2011). Moreover, B. subtilis and P. fluorescens have been successfully formulated and commercially available for the biological management of crop diseases (Jayaraj et al., 2005; Mathivanan et al., 2005). Hence, the present investigation was carried out with different biocontrol agents having different modes of action to develop a cheap, easy to use and beneficial strategy for the farmers and to reduce the hazardous effects of pesticides. 


\section{Materials and Methods}

\section{Isolation of pathogen}

L. theobromae was isolated from infected coconut leaves and further purified by the hyphal tip method and identified based on the descriptions of Punithalingam (1976). Cultures were maintained on potato dextrose agar (PDA) at $4{ }^{\circ} \mathrm{C}$.

\section{Isolation and collection of rhizosphere microbes}

The Pseudomonas fluorescens, Trichoderma viride and Bacillus subtilis were isolated from the rhizosphere soil collected from various locations using the specific media, viz. King's B (King et al., 1954), Trichoderma specific media (TSM) (Elad and Chet, 1983) and Nutrient agar (NA), respectively. The Pseudomonas and Bacillus isolates were characterized based on standard biochemical tests (Schaad, 1992; Hildebrand et al., 1994) and the Trichoderma viride was characterized based on by microscopic examination of the morphological and reproductive characters. P. fluorescens (Pf1) and T. viride (TNAU) were obtained from culture collection centre, Dept. of Plant Pathology, TNAU, Coimbatore. B. subtilis (Km1) was isolated from Kambalapatti.

\section{Dual culture assay}

The effectiveness of the bacterial and fungal antagonists, viz. Pseudomonas, $B a$ cillus and Trichoderma isolates against mycelial growth of L. theobromae was tested by dual culture technique in vitro (Dennis and Webster, 1971). For each test, an $8 \mathrm{~mm}$ diam. mycelial disc from a 7-day-old culture of $L$. theobromae was placed on the agar surface of a $90 \mathrm{~mm}$ Petri dish $1 \mathrm{~cm}$ from the edge of the dish. Streaking of P. fluorescens/Bacillus subtilis strains or an $8 \mathrm{~mm}$ diameter mycelial disc from an actively growing Trichoderma sp. culture was done on the agar surface opposite the target pathogen. Three replicated plates were maintained for each treatment. The plates were incubated together with the experimental controls (pathogen without antagonists) at $28 \pm 2{ }^{\circ} \mathrm{C}$ for 7 days, and the radial growth $(\mathrm{mm})$ of the pathogen mycelium was recorded. Per cent inhibition of mycelial growth of the pathogen was calculated.

\section{Field experiment}

Field experiments were carried out during 2011 to 2014 in a randomized block design at four different locations, viz. Angalakurichi, Pethanaickanur and N.M. Sungam areas of Pollachi taluk and Ravanapuram village of Udumalpet taluk, Coimbatore district, Tamil Nadu, India. P. fluorescens Pf1, B. subtilis (Km1) and T. viride (TNAU) isolates were used for field experiments. Three and five days after inoculation of bacterial and fungal cultures in the liquid broths, respectively, were mixed with @ $400 \mathrm{ml} / \mathrm{kg}$ of talc powder along with $5 \mathrm{~g}$ of carboxy methyl cellulose (except for B. subtilis formulation) as 
sticking agent. Talc-based formulations of all the antagonistic organisms were developed individually and mixed together at equal quantity for field evaluation. Trees showing leaf blight symptoms were randomly selected and each tree was considered as a replication, likewise 10 replications were maintained for each treatment. The treatment schedule as follows:

\section{Treatments:}

1. SA of $150 \mathrm{~g}$ of MC along with $5 \mathrm{~kg}$ of $\mathrm{FYM} / \mathrm{palm}$ at quarterly interval.

2. SA of $150 \mathrm{~g}$ of MC along with $5 \mathrm{~kg}$ of $\mathrm{FYM} /$ palm at half yearly interval.

3. SA of $150 \mathrm{~g}$ of MC along with $5 \mathrm{~kg}$ of FYM/palm once in a year.

4. SA of $150 \mathrm{~g}$ of $\mathrm{MC}$ along with $5 \mathrm{~kg}$ of $\mathrm{FYM}+5 \mathrm{~kg}$ NC per palm per year.

5. SA of $300 \mathrm{~g}$ of $\mathrm{MC}$ along with $5 \mathrm{~kg}$ of $\mathrm{FYM} / \mathrm{palm}$ at quarterly interval.

6. SA of $300 \mathrm{~g}$ of MC along with $5 \mathrm{~kg}$ of FYM/palm at half yearly interval.

7. SA of $300 \mathrm{~g}$ of MC along with $5 \mathrm{~kg}$ of FYM/palm once in a year.

8. SA of $300 \mathrm{~g}$ of MC along with $5 \mathrm{~kg}$ of FYM $+5 \mathrm{~kg}$ NC per palm per year.

9. SA of TNAU Bacillus subtilis (Bs1) mixture @ $300 \mathrm{~g}+\mathrm{FYM} 5 \mathrm{~kg} /$ palm at quarterly interval (Standard).

10. SA of TNAU Bacillus subtilis (Bs1) mixture@ $300 \mathrm{~g}+\mathrm{FYM} 5 \mathrm{~kg} / \mathrm{palm}$ at quarterly interval + NC $5 \mathrm{~kg} /$ palm/year.

11. SA of $5 \mathrm{~kg}$ of $\mathrm{NC} /$ palm/year

12. Chemical check (RF of carbendazim $2 \mathrm{~g}+100 \mathrm{ml}$ water) for 3 times at 3 months interval.

13. Control.

Abbreviations: FYM: farm yard manure ( $\mathrm{SA}=$ soil application; $\mathrm{MC}=$ microbial consortia; $\mathrm{NC}=$ neem cake; $\mathrm{RF}=$ root feeding)

(150 $\mathrm{g}=50 \mathrm{~g}$ each of $P$. fluorescens (Pf1), B. subtilis (Km 1) and T. viride (TNAU) are talc-based formulations. Similarly equal quantities of all the three are mixed together for $300 \mathrm{~g}$, too)

Pre- and post-treatment observations were carried out on leaf blight incidence on about 25 leaflets from the lower 10 leaves in each palm selected at random and the disease severity was scored based on a score chart of $0-5$ scale $(0-$ No infection; $1-<10 \% ; 2$ $-11-25 \%$; $3-26-50 \% ; 4-51-75 \% ; 5->75 \%$ leaf area infected). The per cent disease index (PDI) was calculated based on the formula

$$
\text { PDI }=\begin{array}{lc}
\text { Sum of numerical ratings } & 100 \\
\hdashline \text { No. of leaves examined } & \begin{array}{c}
\text { Maximum grade available } \\
\text { in the score chart (5) }
\end{array}
\end{array}
$$

\section{Statistical analysis}

In vitro experiments were repeated three times. Field experiments were conducted at Angalakurichi and Pethanaickanur villages for two years during 2011-12, 2012-13 and confirmed at N.M. Sungam and Ravanapuram villages during 2013-2014. In each location, trees showing leaf blight symptoms were randomly selected and 10 trees were 
labelled for each treatment and scored. The data were statistically analyzed using the IRRISTAT version 92 developed by the International Rice Research Institute (IRRI) Biometrics unit, the Phillippines (Gomez and Gomez, 1984). Prior to statistical analysis of variance (ANOVA) the percentage values of the disease indices were arcsine transformed. Means \pm standard errors are indicated. Data were subjected ANOVA at $\mathrm{P}<0.05$ significant level and means were compared by Duncan's multiple range test (DMRT).

\section{Results}

In vitro studies

Five Trichoderma viride isolates, and isolates of $P$. fluorescens and Bacillus sp. ( $\mathrm{n}=10$ each) were isolated from the coconut rhizosphere soil and tested against $L$. theobromae by dual plate technique. The in vitro evaluation revealed that the rhizosphere bacteria P. fluorescens (Pf1) and Bacillus subtilis (Kambalapatti) and the fungi T. viride (TNAU) were found highly effective against the leaf blight pathogen and recorded an inhibition zone of $12.7 \pm 0.35 \mathrm{~mm}, 6.7 \pm 0.37 \mathrm{~mm}$ and $6.5 \pm 0.22 \mathrm{~mm}$, respectively (Fig. 1). Hence, all the three antagonists are combined together to develop microbial consortia and evaluated under field conditions.

\section{In vivo studies}

Field experiments were carried out in farmers' fields at Angalakurichi, Pethanaickanur and N. M. Sungam villages of Pollachi taluk, Coimbatore and Ravanapuram village of Udumalpet taluk, Tirupur during 2011 to 2014 to find out the efficacy of developed microbial consortia against leaf blight disease.

The chemical treatment $\mathrm{T}_{12}$ (root feeding of fungicide Carbendazim @ 2 g/100 ml water for 3 times at 3 months interval) was found to be the best treatment among the others including microbial consortia and resulted in $16.67 \pm 0.73$ per cent reduction in leaf blight disease incidence in both the trials conducted at Angalakurichi and Pethanaickanur villages during 2011-2012 (Table 1). Efficacy of treatment $\mathrm{T}_{12}$ was followed by that of $\mathrm{T}_{5}$ (soil application of microbial consortia @ $300 \mathrm{~g}+\mathrm{FYM} 5 \mathrm{~kg} / \mathrm{palm}$ at quarterly interval) and $\mathrm{T}_{10}$ (TNAU B. subtilis (Bs1) mixture @ $300 \mathrm{~g}+\mathrm{FYM} 5 \mathrm{~kg} / \mathrm{palm}$ at quarterly interval + neem cake $5 \mathrm{~kg} / \mathrm{palm} /$ year) in both the trials and showed a disease reduction of $14.53 \pm 1.40,14.40 \pm 0.60$ per cent in Angalakurichi trial and 14.40 \pm 1.13 and $14.13 \pm 0.70$ per cent in Pethanaickanur trial, respectively (Table 1 ).

Similarly, during 2012-2013 season, the chemical treatment $\mathrm{T}_{12}$ was found to be the best treatment among the others and recorded $8.67 \pm 0.76$ per cent and $9.47 \pm 1.01$ per cent reduction in leaf blight disease incidence in Angalakurichi and Pethanaickanur trials, respectively. The efficacy of treatment $\mathrm{T}_{12}$ was followed by those of $\mathrm{T}_{5}, \mathrm{~T}_{9}$ and $\mathrm{T}_{10}$ in both the trials and showed $8.00 \pm 1.37,8.07 \pm 0.69,8.00 \pm 0.89$ per cent and $8.27 \pm 1.27$, $8.13 \pm 0.87,8.00 \pm 0.63$ per cent reduction in the disease incidence both in Angalakurichi and Pethanaickanur trials, respectively (Table 1). 


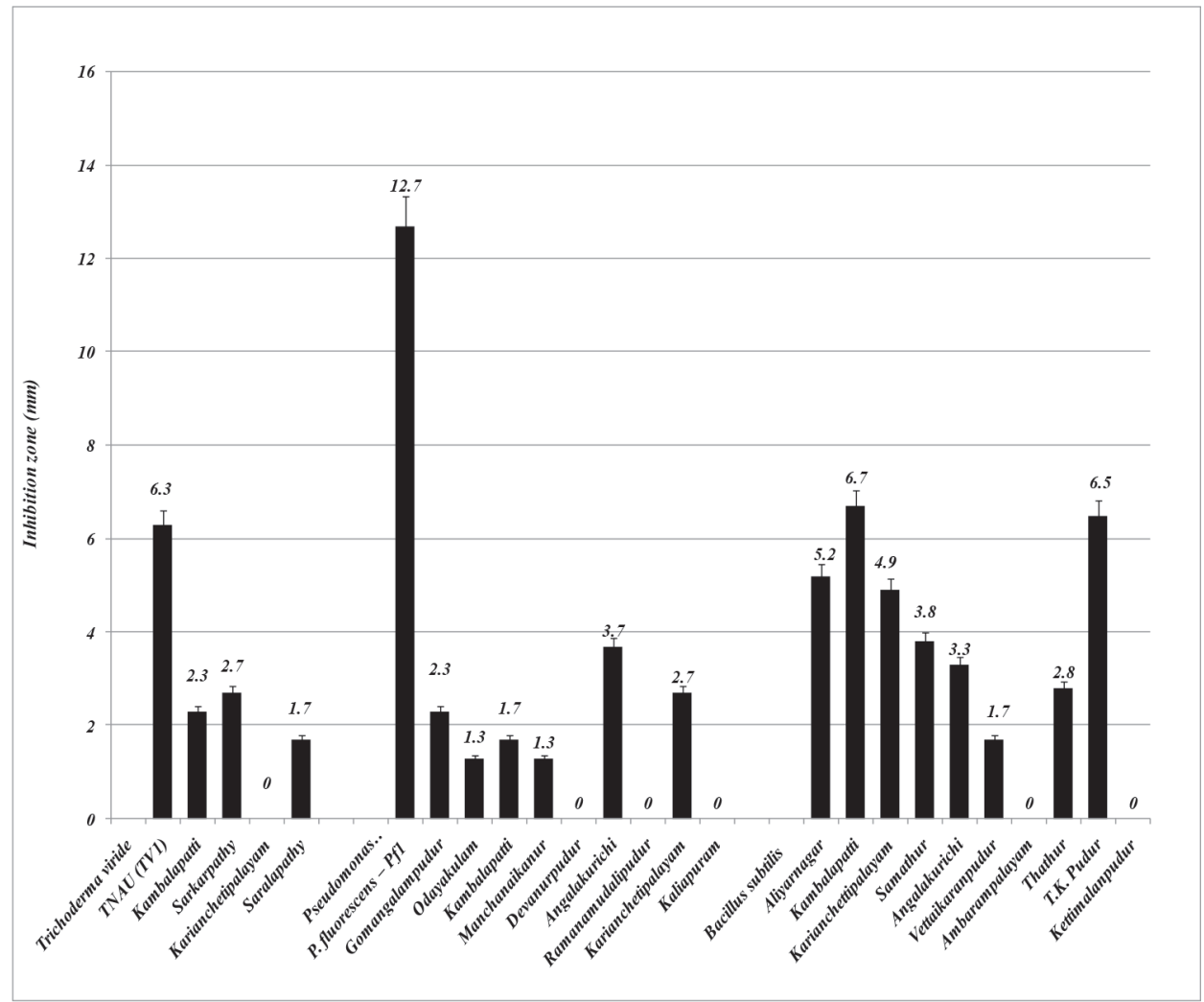

Fig. 1. Mycelial growth inhibition of Lasiodiplodia theobromae by bacterial and fungal antagonists $(\mathrm{mm})$. Bars represent mean \pm standard errors of three independent experiments.

" 0 " Value means represent there is no inhibition of mycelia growth observed in vitro assay

During 2013-2014, similar results were observed from trials laid out at N.M. Sungam, Pollachi taluk, Coimbatore district and Ravanapuram, Udumalpet taluk, Tirupur district. But in the trial laid out at NM Sungam, the treatment $\mathrm{T}_{1}$ (soil application of microbial consortia @ 150 g + FYM 5 kg at quarterly interval) resulted in $9.84 \pm 1.54$ per cent reduction in leaf blight incidence and found on par with $\mathrm{T}_{5}, \mathrm{~T}_{9}$ and $\mathrm{T}_{10}$ which showed $11.44 \pm 0.69,11.04 \pm 0.56$ and $11.52 \pm 0.81$ per cent decrease in symptoms, respectively (Table 1).

\section{Pooled analysis:}

Observations recorded in all the six trials carried out at different locations from 2011-2014 were pooled together and analyzed using IRRISTAT programme. The pooled analysis data (Table 2) clearly indicated that chemical treatment $\mathrm{T}_{12}$ (root feeding of Carbendazim@2 g/100 ml water for 3 times at 3 months interval) was found to be the best among the others and yielded $13.09 \pm 2.53$ per cent reduction in leaf blight disease 
Table 1

Effect of microbial consortia against leaf blight disease of coconut at different locations during 2011-2014

\begin{tabular}{|c|c|c|c|c|c|c|c|}
\hline \multirow{3}{*}{$\begin{array}{l}\text { Treat- } \\
\text { ments }\end{array}$} & \multirow{3}{*}{$\begin{array}{l}\text { Treatment } \\
\text { details }\end{array}$} & \multicolumn{6}{|c|}{ Reduction in disease severity } \\
\hline & & \multicolumn{2}{|c|}{ 2011-2012 } & \multicolumn{2}{|c|}{$2012-2013$} & \multicolumn{2}{|c|}{ 2013-2014 } \\
\hline & & Angalakurichi & Pethanaickanur & Angalakurichi & $\begin{array}{c}\text { Pethanaicka- } \\
\text { nur }\end{array}$ & $\begin{array}{c}\text { N.M. } \\
\text { Sungam }\end{array}$ & Ravanapuram \\
\hline $\mathrm{T}_{1}$ & $\begin{array}{l}\text { MC @ } 150 \mathrm{~g}+\mathrm{FYM} \\
5 \mathrm{~kg} \text { at quarterly } \\
\text { interval }\end{array}$ & $\begin{array}{l}11.99 \pm 1.01^{\mathrm{bc}} \\
(20.20)\end{array}$ & $\begin{array}{l}10.80 \pm 1.30^{\text {cde }} \\
(19.02)\end{array}$ & $\begin{array}{l}6.00 \pm 0.80^{\mathrm{bc}} \\
(13.98)\end{array}$ & $\begin{array}{l}5.73 \pm 0.62^{\mathrm{bc}} \\
(13.77)\end{array}$ & $\begin{array}{l}9.84 \pm 1.54^{\mathrm{bc}} \\
(17.84)\end{array}$ & $\begin{array}{l}6.16 \pm 1.10^{\text {cde }} \\
(14.01)\end{array}$ \\
\hline $\mathrm{T}_{2}$ & $\begin{array}{l}\text { MC@ } 150 \mathrm{~g}+\mathrm{FYM} \\
5 \mathrm{~kg} \text { at half yearly } \\
\text { interval }\end{array}$ & $\begin{array}{l}9.80 \pm 0.31^{\mathrm{cd}} \\
(18.23)\end{array}$ & $\begin{array}{l}9.60 \pm 0.64^{\mathrm{def}} \\
(18.01)\end{array}$ & $\begin{array}{l}4.13 \pm 0.87^{\mathrm{cd}} \\
(11.57)\end{array}$ & $\begin{array}{l}4.27 \pm 1.00^{\mathrm{cd}} \\
(11.70)\end{array}$ & $\begin{array}{l}7.08 \pm 0.66^{\mathrm{de}} \\
(15.28)\end{array}$ & $\begin{array}{l}4.96 \pm 0.25^{\mathrm{def}} \\
(12.84)\end{array}$ \\
\hline $\mathrm{T}_{3}$ & $\begin{array}{l}\text { MC @ } 150 \mathrm{~g}+\mathrm{FYM} \\
5 \mathrm{~kg} \text { once in a year }\end{array}$ & $\begin{array}{l}6.85 \pm 0.66^{\mathrm{e}} \\
(15.10)\end{array}$ & $\begin{array}{l}5.73 \pm 0.73^{\mathrm{g}} \\
(13.75)\end{array}$ & $\begin{array}{l}3.02 \pm 0.67^{\mathrm{d}} \\
(9.75)\end{array}$ & $\begin{array}{l}3.07 \pm 1.04^{\mathrm{de}} \\
(9.49)\end{array}$ & $\begin{array}{l}4.84 \pm 0.89^{f} \\
(12.24)\end{array}$ & $\begin{array}{l}3.36 \pm 0.55^{f} \\
(10.31)\end{array}$ \\
\hline $\mathrm{T}_{4}$ & $\begin{array}{l}\mathrm{MC} @ 150 \mathrm{~g}+\mathrm{FYM} \\
5 \mathrm{~kg}+\mathrm{NC} 5 \mathrm{~kg} \text { once } \\
\text { in a year }\end{array}$ & $\begin{array}{l}8.73 \pm 1.59^{\mathrm{de}} \\
(16.96)\end{array}$ & $\begin{array}{l}8.23 \pm 2.36^{\mathrm{fg}} \\
(15.99)\end{array}$ & $\begin{array}{l}2.73 \pm 0.51^{\mathrm{d}} \\
(9.08)\end{array}$ & $\begin{array}{l}3.20 \pm 0.43^{\mathrm{de}} \\
(10.01)\end{array}$ & $\begin{array}{l}5.78 \pm 0.51^{\mathrm{ef}} \\
(13.78)\end{array}$ & $\begin{array}{l}3.76 \pm 0.36^{\mathrm{f}} \\
(11.08)\end{array}$ \\
\hline $\mathrm{T}_{5}$ & $\begin{array}{l}\text { MC@ @ } 300 \mathrm{~g}+\mathrm{FYM} \\
5 \mathrm{~kg} \text { at quarterly } \\
\text { interval }\end{array}$ & $\begin{array}{l}14.53 \pm 1.40^{\mathrm{ab}} \\
(22.32)\end{array}$ & $\begin{array}{l}14.40 \pm 1.13^{\mathrm{ab}} \\
(22.24)\end{array}$ & $\begin{array}{l}8.00 \pm 1.37^{\mathrm{ab}} \\
(16.28)\end{array}$ & $\begin{array}{l}8.27 \pm 1.27^{\mathrm{ab}} \\
(16.48)\end{array}$ & $\begin{array}{l}11.44 \pm 0.69^{\mathrm{bc}} \\
(19.70)\end{array}$ & $\begin{array}{l}8.56 \pm 1.59^{\mathrm{bc}} \\
(16.54)\end{array}$ \\
\hline $\mathrm{T}_{6}$ & $\begin{array}{l}\text { MC @ } 300 \mathrm{~g}+\mathrm{FYM} \\
5 \mathrm{~kg} \text { at half yearly } \\
\text { interval }\end{array}$ & $\begin{array}{l}11.80 \pm 1.11^{\mathrm{bc}} \\
(20.00)\end{array}$ & $\begin{array}{l}11.60 \pm 1.29^{\mathrm{bcd}} \\
(19.80)\end{array}$ & $\begin{array}{l}5.90 \pm 1.02^{\mathrm{bc}} \\
(13.84)\end{array}$ & $\begin{array}{l}5.87 \pm 1.33^{\mathrm{bc}} \\
(13.62)\end{array}$ & $\begin{array}{l}8.88 \pm 0.58^{\mathrm{cd}} \\
(17.27)\end{array}$ & $\begin{array}{l}6.88 \pm 0.42^{\text {bcd }} \\
(15.15)\end{array}$ \\
\hline $\mathrm{T}_{7}$ & $\begin{array}{l}\mathrm{MC} @ 300 \mathrm{~g}+\mathrm{FYM} \\
5 \mathrm{~kg} \text { once in a year }\end{array}$ & $\begin{array}{l}9.63 \pm 0.35^{\mathrm{cd}} \\
(18.07)\end{array}$ & $\begin{array}{l}8.53 \pm 1.35^{\mathrm{efg}} \\
(16.75)\end{array}$ & $\begin{array}{l}3.80 \pm 0.74^{\mathrm{cd}} \\
(11.07)\end{array}$ & $\begin{array}{l}3.87 \pm 0.76^{\mathrm{cd}} \\
(11.09)\end{array}$ & $\begin{array}{l}6.64 \pm 0.45^{\mathrm{de}} \\
(14.86)\end{array}$ & $\begin{array}{l}4.40 \pm 0.98^{\text {ef }} \\
(11.69)\end{array}$ \\
\hline $\mathrm{T}_{8}$ & $\begin{array}{l}\text { MC@ @ } 300 \mathrm{~g}+\mathrm{FYM} \\
5 \mathrm{~kg}+\mathrm{NC} 5 \mathrm{~kg} \text { once } \\
\text { in a year } \\
\text { TNAU Bs1 mixture }\end{array}$ & $\begin{array}{l}10.68 \pm 0.79^{\mathrm{cd}} \\
(19.03)\end{array}$ & $\begin{array}{l}9.87 \pm 0.77^{\text {def }} \\
(18.25)\end{array}$ & $\begin{array}{l}3.98 \pm 0.41^{\mathrm{ab}} \\
(11.46)\end{array}$ & $\begin{array}{l}3.47 \pm 0.87^{\mathrm{de}} \\
(10.28)\end{array}$ & $\begin{array}{l}6.96 \pm 0.53^{\mathrm{de}} \\
(15.21)\end{array}$ & $\begin{array}{l}4.48 \pm 0.62^{\mathrm{ef}} \\
(11.79)\end{array}$ \\
\hline $\mathrm{T}_{9}$ & $\begin{array}{l}-(300 \mathrm{~g})+\mathrm{FYM} \\
5 \mathrm{~kg} @ \text { quarterly in- } \\
\text { terval }\end{array}$ & $\begin{array}{l}13.73 \pm 0.83^{b} \\
(21.71)\end{array}$ & $\begin{array}{l}13.73 \pm 0.89^{\mathrm{abc}} \\
(21.71)\end{array}$ & $\begin{array}{l}8.07 \pm 0.69^{a b} \\
(16.39)\end{array}$ & $\begin{array}{l}8.13 \pm 0.87^{a b} \\
(16.52)\end{array}$ & $\begin{array}{l}11.04 \pm 0.56^{\mathrm{bc}} \\
(19.36)\end{array}$ & $\begin{array}{l}8.64 \pm 0.71^{b} \\
(16.99)\end{array}$ \\
\hline $\mathrm{T}_{10}$ & $\begin{array}{l}\text { TNAU Bs1 mixture } \\
(300 \mathrm{~g})+\text { FYM } 5 \mathrm{~kg} \\
@ \text { quarterly inter- } \\
\text { val + NC } 5 \mathrm{~kg} \\
\text { (once in a year) }\end{array}$ & $\begin{array}{l}14.40 \pm 0.60^{\mathrm{ab}} \\
(22.28)\end{array}$ & $\begin{array}{l}14.13 \pm 0.70^{\mathrm{ab}} \\
(22.06)\end{array}$ & $\begin{array}{l}8.00 \pm 0.89^{\mathrm{ab}} \\
(16.38)\end{array}$ & $\begin{array}{l}8.00 \pm 0.63^{\mathrm{ab}} \\
(16.34)\end{array}$ & $\begin{array}{l}11.52 \pm 0.81^{b} \\
(19.76)\end{array}$ & $\begin{array}{l}8.56 \pm 0.89^{b} \\
(16.85)\end{array}$ \\
\hline $\mathrm{T}_{11}$ & $\begin{array}{l}\mathrm{NC} \text { alone }-5 \mathrm{~kg} / \\
\text { palm/year } \\
\text { Carbendazim }\end{array}$ & $\begin{array}{l}2.27 \pm 0.66^{\mathrm{f}} \\
(8.25)\end{array}$ & $\begin{array}{l}3.03 \pm 0.53^{\mathrm{h}} \\
(9.88)\end{array}$ & $\begin{array}{l}1.20 \pm 0.27^{\mathrm{e}} \\
(6.20)\end{array}$ & $\begin{array}{l}1.90 \pm 0.83^{\mathrm{e}} \\
(7.14)\end{array}$ & $\begin{array}{l}2.32 \pm 0.41^{g} \\
(8.47)\end{array}$ & $\begin{array}{l}1.28 \pm 0.22^{g} \\
(6.31)\end{array}$ \\
\hline $\mathrm{T}_{12}$ & $\begin{array}{l}(2 \mathrm{~g} / 100 \mathrm{ml} \text { water }) \\
\text { RF } 3 \text { times } \\
\text { at } 3 \text { months interval }\end{array}$ & $\begin{array}{l}16.67 \pm 0.73^{\mathrm{a}} \\
(24.07)\end{array}$ & $\begin{array}{l}16.67 \pm 1.02^{\mathrm{a}} \\
(24.06)\end{array}$ & $\begin{array}{l}8.67 \pm 0.76^{\mathrm{a}} \\
(17.06)\end{array}$ & $\begin{array}{l}9.47 \pm 1.01^{\mathrm{a}} \\
(17.90)\end{array}$ & $\begin{array}{l}14.96 \pm 0.86^{\mathrm{a}} \\
(22.70)\end{array}$ & $\begin{array}{l}12.08 \pm 1.11^{\mathrm{a}} \\
(20.19)\end{array}$ \\
\hline $\mathrm{T}_{13}$ & Control & $\begin{array}{l}4.67 \pm \\
0.97(+)\end{array}$ & $4.93 \pm 0.42(+)$ & $\begin{array}{l}2.80 \pm \\
0.67(+)\end{array}$ & $3.03 \pm 1.08(+)$ & $\begin{array}{l}1.92 \pm \\
0.61(+)\end{array}$ & $2.96 \pm 0.69(+)$ \\
\hline
\end{tabular}

MC: Microbial consortia; FYM: Farm Yard Manure; NC: Neem Cake; RF: Root Feeding

Means \pm standard errors are shown. Values marked with different letters are significantly different at $\mathrm{P}<0.05$, based on Duncan's multiple range test. In control (+) indicates the disease progression 
Table 2

Pooled analysis of reduction in leaf blight disease severity from all the locations over the years from 2011 to 2014

\begin{tabular}{|c|c|c|}
\hline $\begin{array}{l}\text { Treat- } \\
\text { ments }\end{array}$ & Treatment details & $\begin{array}{l}\text { Means of three-year pooled data } \\
\text { of leaf blight disease severity }\end{array}$ \\
\hline $\mathrm{T}_{1}$ & MC @150 g + FYM 5 kg at quarterly interval & $8.42 \pm 1.77^{\mathrm{c}}$ \\
\hline $\mathrm{T}_{2}$ & MC@150 g + FYM 5 kg at half yearly interval & $6.64 \pm 1.81^{\mathrm{d}}$ \\
\hline $\mathrm{T}_{3}$ & MC@150g + FYM 5 kg once in a year & $4.48 \pm 1.86^{\mathrm{e}}$ \\
\hline $\mathrm{T}_{4}$ & MC@150 g + FYM 5 kg + Neem Cake 5 kg once in a year & $5.41 \pm 1.89^{\mathrm{e}}$ \\
\hline $\mathrm{T}_{5}$ & MC@300 g +FYM 5 kg at quarterly interval & $10.87 \pm 1.93^{\mathrm{b}}$ \\
\hline $\mathrm{T}_{6}$ & MC@300 g + FYM 5 kg at half yearly interval & $8.49 \pm 1.94^{\mathrm{c}}$ \\
\hline $\mathrm{T}_{7}$ & MC@ @300 g + FYM 5 kg once in a year & $6.15 \pm 2.02^{\mathrm{d}}$ \\
\hline $\mathrm{T}_{8}$ & MC@300 g +FYM 5 kg + Neem Cake 5 kg once in a year & $6.57 \pm 2.13^{\mathrm{d}}$ \\
\hline $\mathrm{T}_{9}$ & BS1 mixture - TNAU (300 g)+FYM 5 kg@ quarterly interval & $10.56 \pm 2.26^{\mathrm{b}}$ \\
\hline $\mathrm{T}_{10}$ & $\begin{array}{l}\text { BS1 mixture - TNAU ( } 300 \mathrm{~g})+ \text { FYM } 5 \text { kg @ quarterly interval + } \\
\text { Neem cake } 5 \mathrm{~kg} \text { (once in a year) }\end{array}$ & $10.77 \pm 2.38^{\mathrm{b}}$ \\
\hline $\mathrm{T}_{11}$ & Neem cake alone $-5 \mathrm{~kg} / \mathrm{palm} /$ year & $2.00 \pm 0.45^{\mathrm{f}}$ \\
\hline $\mathrm{T}_{12}$ & Carbendazim ( $2 \mathrm{~g} / 100 \mathrm{ml}$ water) RF 3 times at 3 months interval & $13.09 \pm 2.53^{\mathrm{a}}$ \\
\hline $\mathrm{T}_{13}$ & Control & $3.39 \pm 0.52(+)$ \\
\hline
\end{tabular}

Means of pooled disease severity ratings from 2011 to $2014 \pm$ standard errors are shown. Values marked with different letters are significantly different at $\mathrm{P}<0.05$. based on Duncan's multiple range test.

incidence. The efficiency of treatment $\mathrm{T}_{12}$ was followed by that of $\mathrm{T}_{5}$ (soil application of microbial consortia @ $300 \mathrm{~g}+\mathrm{FYM} 5 \mathrm{~kg} / \mathrm{palm}$ at quarterly interval) that showed $10.87 \pm 1.93$ per cent reduction in the disease incidence. The treatments $\mathrm{T}_{10}$ (TNAU Bs1 mixture - @ $300 \mathrm{~g}+\mathrm{FYM} 5 \mathrm{~kg} / \mathrm{palm}$ at quarterly interval + neem cake $5 \mathrm{~kg} / \mathrm{palm} /$ year) and $\mathrm{T}_{9}$ (TNAU Bs1 mixture consortia @ $300 \mathrm{~g}+\mathrm{FYM} 5 \mathrm{~kg} / \mathrm{palm}$ at quarterly interval) showed $10.77 \pm 2.38$ and $10.56 \pm 2.26$ per cent reduction in the disease incidence, respectively and were on par with $\mathrm{T}_{5}$.

\section{Discussion}

In all the three years of evaluation, soil application of microbial consortia $\mathrm{T}_{5}(P$. fluorescens $\mathrm{Pf} 1+T$. viride TNAU B. subtilis $+\mathrm{Km} 1) @ 300 \mathrm{~g}+$ farm yard manure $5 \mathrm{~kg} / \mathrm{palm}$ at quarterly interval was found effective against leaf blight disease next to the standard check Carbendazim (root feeding @2 g/100 ml water for 3 times at 3 months interval). Hence, the microbial consortia developed may be included as a component in the integrated diseases management strategies for leaf blight disease management. 
Sharma et al. (2009) reported the inhibitory potential of $P$. fluorescens against citrus stem end root rot pathogen Botryodiplodia theobromae, while Srinivasulu et al. (2008) reported that spraying of 10 to 15-day-old culture filtrate of $P$. fluorescens twice at 30 days interval on crown region and on nuts of coconut reduced the bud rot incidence.

While Bokhari et al. (2008) reported that the application of T. harzianum along with Topsin-M effectively controlled the pathogens of guava decline disease, viz. B. theobromae, Fusarium oxysporum f. sp. psidii. Srinivasulu and Raghava Rao (2009) reported that the application of Trichoderma spp. caused lysis of the mycelium of Ganoderma lucidum which causes basal stem rot/Thanjore wilt disease in coconut. Furthermore, they have found that the application of $T$. harzianum/T. viride/T. hamatum pasted over bleeding patches and soil application of the bioagents @ $50 \mathrm{~g}$ in $5 \mathrm{~kg}$ neem cake has reduced the perimeter of the stem bleeding patches on coconut trees.

Moreover the type and rate of organic amendment can strongly influence the quality and subsequent crop performance in the field as well as rhizosphere bacterial communities (Allison et al., 2011). Srinivasan (2009) reported that certain bacteria (P. fluorescens, B. subtilis) and fungi (T. viride) have been found to kill or prevent the growth of the major pathogens of leaf rot and hence amelioration of leaf rot disease is possible with the use of biocontrol agents. Such instances of using bacteria and fungi are common in the control of various plant diseases (Ramjegathesh et al., 2013).

Application of two biocontrol agents together, a yeast (Pichia guilermondii) and a bacterium (Bacillus mycoides) resulted in better suppression of Botrytis cinerea, and also reduced the variability of disease control (Guetsky et al., 2001). Hence, application of more than one biocontrol agent is suggested as a reliable means of reducing the variability and increasing the reliability of biological control (Shtienberg and Elad, 2002). The bacterial antagonists may have various modes of actions which includes substrate competition, production of siderophore (Scher and Baker, 1982), antibiotics (Shanahan et al., 1992), enzymes, viz. chitinase, gluconase, cellulose, pectinase, protease etc. (Raupach et al., 1996; Van Loon et al., 1998; Vidhyasekaran et al., 2001; Ramamoorthy and Samiyappan, 2001) and enhance the plant growth and yield either directly or indirectly by production of plant growth regulators, hormones like indole acetic acid, gibberlic acid, cytokinins and ethylene (Arshad and Frankenberger, 1993) and solubilization of minerals and nutrients (Gaur, 1990; Cattelan et al., 1999).

Multiple strain mixtures of microbial agents such as mixtures of fungi, mixtures of bacteria and combination of bacteria with fungi had been employed to enhance the consistancy of control (Duffy and Weller, 1995; Schisler et al., 1997; Nandakumar et al., 2001). Use of several antagonists with different mode of action may improve biocontrol efficacy under wide range of environmental conditions; however; the success of biological control of plant diseases depends up on the availability of effective formulations of biocontrol agents, survival during storage as well as rapid multiplication and colonization after inoculation. Karthikeyan et al. (2008) reported that the talc-based formulation of mix cultures containing B. subtilis, P. fluorescens, Gliocladium virens and Trichoderma spp. could significantly reduced the leaf blight incidence and increased growth of onion in both glass house and field trials. 
Consortia of native rhizosphere bacteria Bacillus megaterium with T. harzianum are able to manage root-knot nematode Meloidogyne incognita infestation in Bacopa monnieri. L effectively and even performed better than chemical nematicides as they colonize root and have direct interaction making impact on plant health and nematode management (Gupta et al., 2014).

Beneficial rhizosphere microbes increased the root growth resulting in greater root surface area which enables the plant to access more nutrients from soil (Patten and Glick, 2002; Suzuki et al., 2004). Many PGPRs stimulated plant growth either by improving plant nutrition, by releasing plant growth regulators or by suppressing pathogenic organisms (Solano et al., 2008). The rhizosphere antagonists including strains of PGPR are associated with (1) fixing atmospheric nitrogen and supplying it to plants (2) synthesizing various phytohormones including auxins and cytokinins (3) providing mechanisms for the solubilization of minerals such as phosphorous (4) antibiotic synthesis (Haas and Defago, 2005). Certain compatible rhizosphere antagonists mixtures enhanced the plant defense by inducing peroxidase (PO), polyphenol oxidase (PPO), PR proteins, lignifiaction, superoxide dismutase and phenolic compounds. Therefore, these beneficial microorganisms can significantly contribute to plant health and function as major component in integrated disease management systems.

\section{Acknowledgement}

This part of the work was done under All India Co-ordinated Research Project on Palms, ICAR.

\section{Literature}

Allison, L. H., Jacka Rangarajan, A., Culman, S. W., Sooksa-Nguand, T. and Thiese, J. E. (2011): Choice of organic amendments in tomato transplants has lasting effects on bacterial rhizosphere communities and crop performance in the field. Appl. Soil Ecol. 48, 94-101.

Arshad, M. and Frankenberger, W. T. (1993): Microbial production of plant growth regulators. In: F. B. Metting, Soil Microbial Ecology Applications in Agricultural and Environmental Management. Marcel Dekker Inc., New York, pp. 307-347.

Asaka, O. and Shoda, M. (1996): Biocontrol of Rhizoctonia solani damping-off of tomato with Bacillus subtilis RB14. Appl. Env. Microbiol. 62, 4081-4085.

Bokhari, A. A., Sahi, S. T., Khan, M. A., Ahmad, R. and Islam-ud-Din (2008): In vivo studies on the biological and chemical control of guava decline caused by different soil borne pathogens. Pak. J. Agric. Sci. 45, 54-56.

Cattelan, A. J., Hartel, P. G. and Fuhrmann, J. J. (1999): Screening for plant growth promoting rhizobacteria to promote early soybean growth. Soil Sci. Soc. America J. 63, 1670-1680.

Dennis, C. and Webster, J. (1971): Antagonistic properties of species-groups of Trichoderma III: Hyphal interaction. Trans British Mycol. Soc. 57, 363-369.

Duffy, B. K. and Weller, D. M. (1995): Use of Gaeumannomyces graminis var. graminis alone and in combination with fluorescent Pseudomonas spp. to suppress take-all of wheat. Plant Dis. 70, 907-911.

Elad, Y. and Chet, I. (1983): Improved selective media for isolation of Trichoderma spp. and Fusarium spp. Phytoparasitica 11, 55-58.

Galindo, J. J. (1992): Prospects for biological control of cacao. In: P. J. Keane and C. A. Putter (eds): Cocoa pest and disease management in Southeast Asia and Australasia. Rome, FAO Plant Production and Protection Paper $112 \mathrm{p}$. 
Gaur, A. C. (1990): Phosphate Solubilising Microorganisms as Biofertilizers. Omega Scientific Publishers, New Delhi, India, 198 p.

Gomez, K. A. and Gomez, A. A. (1984): Statistical Procedure for Agricultural Research. John Wiley and Sons, New York, 407 p.

Grosch, R., Schneider, J. H. M., Kofoet, A. and Feller, C. (2011): Impact of continuous cropping of lettuce on the disease dynamics of bottom rot and genotypic diversity of Rhizoctonia solani AG 1-IB. J. Phytopathol. $59,35-44$.

Guetsky, R., Shtienberg, D., Elad, Y. and Dinoor, A. (2001): Combining biocontrol agents to reduce the variability of biological control. Phytopathology 91, 621-627.

Gupta, R., Tiwari, S., Saikia, S. K., Shukla, V., Singh, R., Singh, S. P., Ajaykumar, P. V. and Pandey, R. (2014): Exploitation of microbes for enhancing bacoside content and reduction of Meloidogyne incognita infestation in Bacopa monnieri. L. Protoplasma 252, 53-61.

Haas, D. and Defago, G. (2005): Biological control of soil-borne pathogens by fluorescent pseudomonads. National Review of Microbiology 1, 1-13.

Hildebrand, D. C., Schroth, M. N. and Sands, D. C. (1994): Pseudomonas. In: Laboratory Guide for Identification of Plant Pathogenic Bacteria. $2^{\text {nd }}$ ed. ed. by N. W. Schaad Am. Phytopath. Soc., St Paul, MN. pp. 60-80.

Jayaraj, J., Radhakrishnan, N. V., Kannan, R., Sakthivel, K., Suganya, D., Venkatesan, S. and Velazhahan, R. (2005): Development of new formulations of Bacillus subtilis for management of tomato damping-off caused by Pythium aphanidermatum. Bio. Sci. Tech. 15, 55-65.

Johnson, I., Meena, B. and Rajamanickam, K. (2014): Biological management of leaf blight disease of coconut using rhizosphere microbes. J. Plantation Crops 42, 364-369.

Johnston, A. (1965): Host list of fungi etc. and insects recorded in the South East Asia and Pacific region - Cocos nucifera L.- coconut (English). FAO, Bangkok, Thailand, Plant Protection Committee for the South East Asia and Pacific Region, Technical Doc. No. 16, Second ed. 19 p.

Karthikeyan, A. and Bhaskaran, R. (1998): Evaluation of fungicides in control of leaf blight disease of coconut caused by Pestalotia palmarum (Cooke) stey. Indian Coconut J. (Cochin). 28, 6-8.

Karthikeyan, M., Radhika, K., Bhaskaran, R., Mathiyazhagan, S., Sandosskumar, R., Velazhahan, R. and Alice, D. (2008): Biological control of onion leaf blight disease by bulb and foliar application of powder formulation of antagonist mixture. Arch. Phytopath. Pl. Prot. 41, 407-417.

Kim, G. H., Lim, M. T., Hur, J. S., Yum, K. J. and Koh, Y. J. (2009): Biological control of tea anthracnose using an antagonistic bacterium of Bacillus subtilis isolated from tea leaves. Plant Path. J. 25, 99-102.

King, E. O., Ward, M. K. and Raney, D. E. (1954): Two simple media for the demonstration of pyocyanin and fluorescein. J. Lab. Clinical Medicine 44, 301-307.

Lakshmanan, P. and Jagadeesan, R. (2004): Malformation and cracking of nuts in coconut palms (Cocos nucifera) due to the interaction of the eriophyid mite Aceria guerreronis and Botryodiplodia theobromae in Tamil Nadu. J. Pl. Dis. Protection. 111, 206-207.

Mathivanan, N., Prabavathy, V. R. and Vijayanandraj, R. (2005): Application of talc formulations of Pseudomonas fluorescens Migula and Trichoderma viride Pers. ex. S. F gray decrease the sheath blight disease and enhance the plant growth and yield in rice. J. Phytopathol. 153, 697-701.

Mortuza, M. G. and Ilag, L. L. (1999): Potential for biocontrol of Lasiodiplodia theobromae (Pat.) Griff. and Maubl. in banana fruits by Trichoderma species. Biol. Control 15, 235-240.

Nandakumar, R., Viswanathan, R., Babu, S., Sheela, J., Raguchander, T. and Samiyappan, R. (2001): A new bio-formulation containing plant growth promoting rhizobacterial mixture for the management of sheath blight and enhanced grain yield in rice. Biocontrol 46, 493-510.

Papavizas, G. C. (1985): Trichoderma and Gliocladium: Biology, ecology and potential for biocontrol. Ann. Rev. Phytopath. 23, 23-54.

Parke, J. L., Rand, R. E., Joy, A. E. and King, E. B. (1991): Biological control of Aphanomyces root rot and Pythium damping-off of peas by application of Pseudomonas cepacia or Pseudomonas fluorescens applied to seed. Plant Dis. 75, 987-992. 
Patten, C. L. and Glick, B. R. (2002): Role of Pseudomonas putida indoleacetic acid in development of the host plant root system. Appl. Environ. Microbiol. 68, 3795-3801.

Punithalingam, E. (1976): Botryodiplodia theobromae. CMI Descriptions of Pathogenic Fungi and Bacteria, CAB International, Wallingford, UK. 519, 1-2.

Raju, C. A. (1984): Effect of methyl bromide fumigation on the fungi associated with seed coconuts. Philipp. J. Coconut Stud. 9, 1-2.

Ramamoorthy, V. and Samiyappan, R. (2001): Induction of defence related genes in Pseudomonas fluorescens treated chilli plants in response to infection by Colletotrichum capsici. J. Mycol. Plant Pathol. 31, 146-155.

Ramjegathesh, R., Samiyappan, R., Raguchander, T., Prabakar, K. and Saravanakumar, D. (2013): Plant-PGPR Interactions for Pest and Disease Resistance in Sustainable Agriculture. In: D. K. Maheshwari (ed.): Bacteria in Agrobiology: Disease Management, DOI 10.1007/978-3-642-33639-3-11, Springer-Verlag Berlin Heidelberg. pp. 293-320.

Raupach, G. S., Liu, L., Murphy, J. F., Tuzun, S. and Kloepper, J. W. (1996): Induced systemic resistance in cucumber and tomato against cucumber mosaic cucumo virus using plant growth-promoting rhizobacteria (PGPR). Plant Dis. 80, 891-894.

Raupach, G. S. and Kloepper, J. W. (1998): Mixtures of plant growth promoting rhizobacteria enhance biological control of multiple cucumber pathogens. Phytopathology 88, 1158-1164.

Schaad, N. W. (1992): Laboratory Guide for Identification of Plant Pathogenic Bacteria. $2^{\text {nd }}$ ed. International Book Distributing Co., Lucknow, 164 p.

Scher, F. M. and Baker, R. (1982): Effect of Pseudomonas purida and a synthetic iron chelator on induction of soil suppressiveness to Fusarium wilt pathogens. Phytopathology 72, 1567-1573.

Schisler, D. A., Slininger, P. J. and Bothast, R. J. (1997): Effects of antagonist cell concentration and two strain mixtures on biological control of Fusarium dry rot of potatoes. Phytopathology 87, 177-183.

Shanahan, P., Sullivan, D. J., Simpson, P., Glennon, J. D. and Gara, F. (1992): Isolation of 2,4-diacetylphloroglucinol from a fluorescent pseudomonad and investigation of physiological parameters influencing its production. Appl. Environ. Microbiol. 58, 353-358.

Sharma, R. N., Maharshi, R. P. and Gaur, R. B. (2009): Management of stem and rot of Citrus deliciosa through bio-agents. Annu. Plant Prot. Sci. 17, 114-118.

Shtienberg, D. and Elad, Y. (2002): Is it possible to cope with variability of biological control? IOBC WPRS Bulletin 25, 1-4.

Solano, B. R., Maicas, J. B., De la Iglesia, M. T. P., Domenech, J. and Manero, F. J. G. (2008): Systemic disease protection elicited by plant growth promoting rhizobacteria strains. Relationship between metabolic responses, systemic disease protection, and biotic elicitors. Biol Control, 98, 451-457.

Someya, N., Kataoka, N., Komagata, T., Hibi, T. and Akutsu, A. (2000): Biological control of cyclamen soil borne diseases by Serratia marcescens strain B2. Plant Dis. 84, 334-340.

Srinivasan, N. (2009): Production and utilization of biocontrol agents for sustainable management of plant diseases with special reference to coconut root (wilt) associated leaf rot. In: P. Ponmurugan, M. A. Deepa (eds): Role of Biocontrol Agents for Disease Management in Sustainable Agriculture. SCITECH (India) Pvt., Chennai pp. 507-520.

Srinivasulu, B. and Raghava Rao, D. V. (2009): Biocontrol of major diseases of coonut. In: P. Ponmurugan, and M. A. Deepa (eds): Role of Biocontrol Agents for Disease Management in Sustainable Agriculture. SCITECH (India) Pvt., Chennai pp. 352-368.

Srinivasulu, B., Gaautam, B., Sujatha, A., Kalpana, M., Vijayalakshmi, P., Pavanirani, A., Chandran, B. S. R. S. and Ramakrishna, Y. (2008): Bud rot disease of coconut. Technical Bulletin, AICRP on palms, Horticultural Research Station, Andhra Pradesh Horticultural University, Ambajipeta, 24 p.

Suryadi, Y., Susilowati, D. N., Putri, K. E. and Mubarik, N. R. (2011): Antagonistic activity of indigenous indonesian bacteria as the suppressing agent of rice fungal pathogen. J. Int. Environ. Appl. Sci. 6, 558-568.

Suzuki, H., Xia, Y., Cameron, R., Shadle, G., Blount, J., Lamb, C. and Dixon, R.A. (2004): Signals for local and systemic responses of plants to pathogen attack. J. Exp. Bot, 55, 169-179.

Swain, M. R. and Ray, R. C. (2009): Biocontrol and other beneficial activities of Bacillus subtilis isolated from cow dung microflora. Microbiol. Res. 164, 121-130. 
Swapna, P. K. and Nagaveni, H. C. (2009): Screening of Trichoderma spp. against Lasiodiplodia theobromae causing fruit rot of Elaeocarpus munronii. Indian J. Plant Protect. 37, 166-169.

Van Loon, L. C., Bakker, P. A. H. M. and Pieterse, C. M. J. (1998): Systemic resistance induced by Rhizosphere bacteria. Annu. Rev. Phytopath. 36, 453-483.

Vidhyasekaran, P., Kamala, N., Ramanathan, A., Rajappan, K. and Paranidharan, V. (2001): Induction of systemic resistance by Pseudomonas fluorescens Pf1 against Xanthomonas oryzae pv. oryzae in rice leaves. Phytoparasitica 29, 155-166.

Warwick, D. R. N., Passos, E. E. M., Leal, M. L. S. and Bezerra, A. P. O. (1993): Influence of water stress on the severity of coconut leaf blight caused by Lasiodiplodia theobromae. Oleagineux. 48, 279-282.

Wilson, M. and Lindow, S. E. (1992): Relationship of total viable and culturable cells in epiphytic populations of Pseudomonas syringae. Appl. Env. Microbiol. 58, 3908-3913. 